\title{
Microbial Weathering of Coal for REE Extraction
}

\author{
BRANDON R. BRIGGS ${ }^{1}$, MiCHAEL MARTINEZ ${ }^{2}$, ANKUR \\ SACHAN $^{3}$, TATHAGATA GHOSH ${ }^{4}$ \\ ${ }^{1}$ University of Alaska Anchorage, bbriggs6@alaska.edu \\ ${ }^{2}$ University of Alaska Anchorage, mamartinez9@alaska.edu \\ ${ }^{3}$ University of Alaska Fairbanks, ankurs1788@alaska.edu \\ ${ }^{4}$ University of Alaska Fairbanks, tghosh@alaska.edu
}

The rare earth elements (REEs) are a group of seventeen elements which includes scandium, yttrium, and fifteen of the lanthanide series elements. These elements are vital to the U.S. because they are used in a variety of consumer goods, advancted technology, and in defense purposes. Acquiring a domestic profitable source of REEs is a critial national need. Coal contains REEs and can serve as an alternate source as demonstrated by the fact that some Alaskan coal depostis contain REEs in concentrations as high as $950 \mathrm{ppm}$. Microbes have profoundly affected Earth's surface over geologic time by playing critical roles in weathering of minerals. This project examined the process of bio-weathering coal to release REEs into solution. Alaskan coal was incubated with Shewanella oneidensis at a circum-nuetral $\mathrm{pH}$ and cycled between oxic and anoxic conditions. Total REE had a maximum recovery rate of $98.4 \%$. Abiotic controls did not produce measureable levels of any REE. Futhermore, depending on the source of coal bio-weathering performed compariable to or better than acid leaching $\left(1.2 \mathrm{M} \mathrm{H}_{2} \mathrm{SO}_{4}\right.$ at $75^{\circ} \mathrm{C}$ ). These results show that microbial weathering of coal offer an alternative method to extract REEs that may be more efficient and more environmentally friendly than current technologies. 